EDITORIAL

\title{
Ethics and Politics
}

Ethics and politics are complex concepts, and there is a close relationship between them, which is revealed in the titles of the various studies that follow. Upon analyzing the texts I decided to raise some reflections that may appear diafficult, but I will make an effort to present them clearly. I begin with a small introduction about ethics and will then use illuminations from Hannah Arendt $(2011,2012)$ to discuss how one can think of politics and freedom in a community that seeks to be ethical. I reflected deeply to write this and I encourage the reader to question my reflections.

Ethics is a dimension that is inseparable from the daily life of men and women. This is clear if we examine its very etymology. Both the Greek term ethos, from which ethics is derived, as well as the Latin term mos, the source of the word moral, refer to the same reality: the customs that are established in daily relations between the people of a community. Even now, whenever a group comes together, its participants immediately begin to establish forms of living, how they will undertake their tasks, who will be responsible for what. Tacitly, implicit norms are established, responsibilities for each one, ways of living: these are the customs that become ethics and morals.

It is important to note that the moral or ethical dimension always pervades all human actions. This surprising phenomenon cannot be avoided. All types of action and conviviality intrinsically carry with them a valuative connotation, the presence of values. Values interpenetrate and possess us, it is values that always stimulate us to act. They are part of the very constitution of the human being. Paulo Freire (1997), in an interview given a few days before he died, testified to this in a deeply experiential manner by affirming that it is impossible to think of or do something without being touched and incorporated by this ethical dimension: "we are ethical beings, ethics pervades our entire existence".

In everyday parlance it is commonly said - and this is not incorrect - that both ethics and morals are related to qualifications of good or bad. This question, however, becomes intriguing, and much more complex, when we come to ask about the fundaments of this "good/bad". It is at this point that some begin to distinguish between ethics and morals: morals would be the customs and norms that are implicitly and tacitly established between peoples and groups, without questioning. While ethics would be a critical philosophical reflection about this crucial question: based on which we can affirm that something is good or bad.

Various theories (paradigms, explanations, justifications) have been constructed to respond to this question. There are two principal ones. A first is called naturalism: something is good or bad if it is adequate and responds to the laws of nature. Natural law is the great ethical law. While a second, contractualism, argues that what guarantees whether something is good or bad is positive law, which is created by humans: if there is law, it is presumed that it is good and must be followed. This is the dominant paradigm today. Everyone strives for a law and when they find it, they try to impose it on the others.

I am convinced that it is possible to advance in this reflection. I seek inspiration in the contributions of an important twentieth century thinker, Hannah Arendt. She lived - and intensely suffered the vicissitudes of the century, thinking of them critically. Considered an idealist, or historic romantic, for some, her reflections remain quite current.

Arendt sought in the Greek polis and in the Roman civitas arguments to not only understand, but also to suggest, a new understanding of politics that is compatible and can propitiate a new ethics. It is not necessary to accept that the polis had come to be a universal and generalized way of life for all Greeks. It would be established as an ideal situation in which the people, already freed from labor (work), needed to satisfy their vital needs (the space of need), and having also dominated the command of the obra, the fabrication and transformation of nature (the space of utility) could live with greater plentitude that dimension in which the true 
human is situated, the space of action as discourse, which would be the foundation of a new ethics - an ethics of discourse. This political space was the space of freedom.

Arendt's proposal was to reflect on human action: from the labor of the slave and artificial fabrication of worldliness to action as speech, as discourse, the only action exercised directly between human beings without the mediation of things or matter: the human condition of plurality.

Deepening Arendt's thinking, she began affirming that "what distinguishes the conviviality of men in the polis from all other forms of human conviviality that were well known to the Greeks, was freedom" (ARENDT, 2012, p. 47). Politics was not only a "means" to allow freedom. "To be free and live in a polis were, in a certain sense, one and the same thing" (ARENDT, 2012,p. 47). She then soon explains: "The meaning of politics here, but not its objective, is that men have relations between themselves in freedom, beyond force, coercion and domination [...] [they] regulate all the affairs by means of mutual conversation and reciprocal persuasion" (ARENDT, 2012, p. 48, emphasis mine).

I will comment on these statements. Two central points are related with our case: first, it was not politics that was propitious to freedom: to live in a polis was to live in freedom, it constituted freedom. And this "living in a polis" is what is called ethics, the ethos, the mos, the custom. Second: what constitutes this ethos, this custom? It is precisely the fact that they materialize this ethos by speech, by discourse. In sum: politics was ethics; and ethics was constituted in the ability to speak on equal grounds. To live in the polis was to live freely.

I emphasize one more point. The political act was thus focused on freedom. But this freedom was understood in two complementary manners: negatively, as not being dominated and not dominating; and positively, as a space that can only be produced by many, as she affirms: "without these others, which are my equals, there is no freedom" (ARENDT, 2012, p. 48). This authentic freedom is only possible in a relationship.

One more distinction. In speech we customarily link the concept of equality to that of justice, and not to freedom. Arendt advances once again here by showing the importance of discourse - of speech on equal grounds - as a foundation for ethics. She insists: "isonomy does not mean that everyone is equal before the law, nor that the law is equal for all, but that all have the same right to political activity [...] isonomy is, therefore, essentially the equal right to speak and as such the same as isegoria" (ARENDT, 2012, p. 49). And now, the important detail: "to speak in the form of commanding, and hear in the form of obeying were not considered actual speech and hearing; they were not free [...] but presumed the use of force and being forced" (ARENDT, 2012, p. 49). For this reason, Arendt concludes, the Greeks would say that the slaves and Barbarians were aneu logou, did not have command of the word, were in a situation in which it was impossible to have a free conversation. Here is the importance of speech on equal grounds for a politics constructed by an ethics based on discourse.

I will challenge the readers to experiment with this practice: all have the right, and the responsibility to speak, to raise their project in common. But speech without coercion and without domination: on equal grounds (this is ethics in action). Based on this discourse a political project can be constructed, that is, how the community, the city, should be.

To conclude, we proposed to raise some questions about the relationship between ethics and politics. We began by showing how ethics and its foundations are understood. We introduced the question of politics to argue, based on reflections from Arendt, that it is possible to speak of a new ethics, based on the moment in which we assume and practice a politics based on a discourse on equal grounds. Thus, it will be possible to establish a new foundation for ethics, an ethics of discourse, where people "regulate all issues by means of mutual conversation and reciprocal convincing": a space = freedom, made propitious by ethics and politics. "The indispensable accessory, the constant presence of others, the relationship with equals in the promotion of the ágora, the isegoria becomes the true content of the free-being", where "speech itself is understood a priori as a type of acting" (ARENDT, 2012 p. 56), where acting and speaking are not separated.

Pedrinho Guareschi, July 2017.

\section{References}

ARENDT, H. A Condição Humana. Rio de Janeiro: Forense Universitária, 2011. O que é Política. Rio de Janeiro: Bertrand Brasil, 2012.

FREIRE, P. Paulo Freire in Memoriam. São Paulo: PUCSP - Departamento de Educação, 1997 [vídeo]. 


\section{Pedrinho Guareschi}

pedrinho.guareschi@ufrgs.br

Doutorado em Psicologia Social pela University of Wisconsin, Madison, Wisconsin, EUA

Professor colaborador permanente no Programa de Pós-Graduação em Psicologia Social e Institucional da Universidade Federal do Rio Grande do Sul (UFRGS)

\section{UFRGS}

Rua Ramiro Barcelos, 2600 - bairro Santa Cecília

Porto Alegre - Rio Grande do Sul - Brasil

CEP: 90.035-003 